\title{
Essential Oils of Toona and Cedrela Species (Meliaceae):
}

\section{Taxonomic and Ecological Implications}

\author{
Beatriz H. L. N. S. Maia ${ }^{a}$,José R. de Paula ${ }^{a}$, Josué Sant'Ana ${ }^{a}$, \\ M. Fátima das G. F. da Silva ${ }^{a}$, João B. Fernandes ${ }^{a}$, Paulo C. Vieira ${ }^{a}$, \\ Merilene do S. S. Costa , Orlando S. Ohashi and José Natalino M. Silva \\ ${ }^{a}$ Departamento de Química, Universidade Federal de São Carlos, CP 676, 13565-905 São Carlos, SP, Brazil \\ ${ }^{b}$ Faculdade de Ciências Agrárias do Pará, Belém, PA, Brazil \\ ${ }^{c}$ Empresa Brasileira de Pesquisa Agropecuária, Belém, PA, Brazil
}

\begin{abstract}
Os óleos essenciais de Toona ciliata, Cedrela odorata e C. fissilis foram analisados por CGEM. Cedrela apresentou em maior percentagem sesquiterpenos formados a partir do precursor pirofosfato de cis- e trans-farnesila. Já Toona mostra uma tendência em produzir principalmente sesquiterpenos derivados do pirofosfato de trans-farnesila. Estes resultados confirmam que a classificação destes dois gêneros em uma mesma tribo, Cedreleae, continua problemática. As respostas em eletroantenogramas médios (EAGs) dos óleos essenciais de $T$. ciliata e $C$. odorata, em fêmeas de Hypsipyla grandella, foram significativamente maiores que aquelas obtidas em machos, sugerindo que as fêmeas utilizariam os odores destes óleos para a seleção da planta hospedeira (gêneros de Swietenioidea) e na escolha de locais para oviposição.
\end{abstract}

The essential oils of Toona ciliata, Cedrela odorata and C. fissilis have been analysed by GCMS. Cedrela contains the main sesquiterpenes formed from the cis- and trans-farnesyl pyrophosphate. In contrast, Toona tend to produce mainly sesquiterpenes formed from the trans-precursor. These results show that the affiliation of Toona in the tribe Cedreleae together with Cedrela is still rather problematic. Mean electroantennogram responses (EAGs) to the essential oils from T. ciliata and $C$. odorata, in Hypsipyla grandella females were significantly greater than those obtained for males, suggesting that females would use attractant odours messages from the host-plant (genera of Swietenioideae) as search strategy behaviour for habitat location and oviposition.

Keywords: Meliaceae, essential oil, chemotaxonomy, electroantennogram, gas chromatographyelectroantennographic detection

\section{Introduction}

The family Meliaceae provides the most valuable timbers, such as mahogany (Swietenia) and cedar (Cedrela), which have been illegally exported from Brazil. At present they are scarce and efforts to establish large scale homogeneous plantations have almost invariably failed due to larval attacks by the shoot borer Hypsipyla. Main damage is caused by the larvae, which destroy the succulent terminal shoots by boring into the tip and tunnelling in the juvenile stems of saplings and seedlings. Re-sprouting of the plants, followed by repeated attacks of the insect, generally results in the development of numerous side branches and consequently in badly formed trees, unsuitable for timber production.

*e-mail: dmfs@power.ufscar.br
Hypsipyla grandella is considered to be the most harmful species in Latin America, and H. robusta in Asia and Africa ${ }^{1}$. Toona ciliata, the Australian red cedar, introduced to Brazil shows excellent growth and an absence of attacks by $H$. grandella, in contrast to the native Cedrela odorata ${ }^{2,3}$. However, eggs of $H$. grandella have been found on the Australian cedar in field survey (Belém, Pará, Brazil).

Toona was originally described by Endlicher (1840) as a section of Cedrela. Later Roemer (1846) recognized that it could be separated by a number of sound morphological characters, raising Toona to generic rank ${ }^{4}$. Thus, the old world species of Cedrela were transferred to Toona (Endlicher) M. J. Roemer. The two genera were placed by Harms (1940) in the tribe Cedreleae under Cedreloideae ${ }^{5}$. Pennington and Styles (1975), in their more recent monograph, include Cedreleae into the Swietenioideae ${ }^{6}$. As reported in previous 
papers the known limonoids from Cedrela are typical of the Swietenioideae ${ }^{7-9}$. On the other hand, Toona differs from other genera of this subfamily, notably by the absence of limonoids of the mexicanolide group. Our earlier phytochemical studies on T. ciliata, showed the presence of limonoids with intact carbon skeleton 21-hydroxycedrelonelide, 23-hydroxycedrelonelide, $6 \alpha$-acetoxy-14 $\beta, 15 \beta$-epoxyazadirone and ringsA,C,D-intact-ring-B-seco-limonoids 12-deacetoxytoonacilin, $5 \alpha, 6 \beta, 8 \alpha$-trihydroxy-28-norisotoonafolin and $5 \alpha, 6 \beta, 8 \alpha$, $12 \alpha$-tetrahydroxy-28-norisotoonafolin indicating that the genus is thus indeed akin to the Melioideae ${ }^{10,11}$. Rings-A,C,Dintact-ring-B-seco-limonoids are features that are largely confined to the latter. We have now examined the essential oils of T.ciliata, C.odorata and C. fissilis in order to determine if the above differences still remain also in other classes of secondary metabolites. There is strong evidence that volatile principles of the host play a crucial role in the attraction of the females to oviposit. The electroantennograms (EAGs) were recorded from both sexes of $H$. grandella antennae to determine the stimulating capacity of the essential oils obtained.

\section{Experimental}

\section{Isolation and analysis of volatile oil}

Cedrela odorara and Toona ciliata were collected in Viçosa, MG, while C. fissilis in São Carlos, SP, Brazil; voucher specimens are deposited in the herbarium of Universidade Federal de Viçosa.

The fresh aerial parts of each species were submitted to steam distillation for $4 \mathrm{~h}$, using a Clevenger apparatus. The essential oils obtained were dried over anhydrous $\mathrm{Na}_{2} \mathrm{SO}_{4}$ and kept in the freezer. The analyses of the oils were carried out on a Shimadzu GC-17A gas chromatograph fitted with a fused silica DB-5 (30 m x $0.25 \mathrm{~mm}$ ID, $0.25 \mathrm{~mm}$ film thickness) capillary column with helium as the carrier gas at a flow rate of $1.6 \mathrm{ml} . \mathrm{min}^{-1}$. The temperature was programmed initially at $60^{\circ} \mathrm{C}$ for $2 \mathrm{~min}$, then increased with a rate of $3^{\circ} \mathrm{C} \cdot \mathrm{min}^{-1}$ to $240^{\circ} \mathrm{C}$. The injection was split and its temperature was $225^{\circ} \mathrm{C}$. The interface temperature was $250^{\circ} \mathrm{C}$. The chromatograph was coupled to a Shimadzu QP5000 mass selective detector at $70 \mathrm{eV}$; EIMS and CIMS (methane) for globulol $(\mathrm{RI}=1583)$ and caryophyllene oxide (RI = 1581). Identification of the components was made by determination of their retention indices relative to those of an homologous series of $n$-alkanes ${ }^{12}$, by comparison with a) co-injection with authentic samples, b) fragmentation patterns in mass spectra with those stored on the spectrometer database and bibliography ${ }^{13}$.

\section{Insects}

Larvae of Hypsipyla grandella were collected in the fields of EIDAI, a Japanese timber company based in Belém, $\mathrm{PA}$, Brazil. They were reared in a growth room at $26 \pm 2^{\circ} \mathrm{C}$, $60 \pm 10$ relative humidity and 16:8 hr light-dark photoperiod, at Universidade Federal de São Carlos, SP, Brazil. Pupae were separated by sex and in advanced age they were transported to Universidade Federal de Viçosa, MG, Brazil, where the electrophysiological analyses were conducted.

\section{Electroantennograms (EAGs)}

Antennae from 3-4-day-old males and females were used in the EAG (Syntech Laboratories) measurements. The antennae were cut off at the base. The tip of the terminal segment was removed to enable electric contact with the recording electrode. The tip and the base part were connected to an $\mathrm{Ag}-\mathrm{AgCl}$ capillary electrodes filled with $0.1 \mathrm{~N} \mathrm{KCl}$ with a small amount (5\% by volume) of Polyvinylpyrrolidone (PVP).

Stimulus were delivered from glass odor cartridges (80mm long X 5mm ID) as $5 \mathrm{ml}$ aliquots on Whatman no. 1 filter paper pieces $(7 \mathrm{~mm} \times 18 \mathrm{~mm})$. These odor cartridges were oriented towards the antenna and placed $1 \mathrm{~cm}$ away from the preparation. Odor molecules evaporating from the filter paper were carried over the preparation by humidifier air. Stimulus duration was $1 \mathrm{sec}$. Interstimulus time intervals of $1 \mathrm{~min}$. was allowed for recovery of the sensory cells. Control stimulations using air and filter paper impregnated with $10 \mu \mathrm{l}$ of hexane solvent were made at the beginning of each preparation. Maximal depolarization of the EAG during the stimulation period was used as a measure of antennal stimulation by the odorous stimulus.

The signal was amplified by a Data Acquisition Interface Board, Type IADC-02, developed by Syntech Laboratories and viewed on a EAG software package for WINDOWS.

Coupled gas chromatography-electroantennographic detection (GC-EAD)

The GC-EAD measurements were performed in a Shimadzu 17 A. GC with helium as carrier $(50 \mathrm{~cm} / \mathrm{s})$, equipped with an Supelcowax 10 column $(0.25$ film, 30m x $0.25 \mathrm{~mm}$ ID). Chromatographic parameters were as follows: initial oven $100^{\circ} \mathrm{C}$ for 2 minutes, followed by a ramp of $5^{\circ} \mathrm{C} / \mathrm{min}$. to a final temperature of $240^{\circ} \mathrm{C}$. Injections were done with split mode only. The sample was equally split between a flame ionization detector (FID) and the EAG detector. The EAG recorder, software, IADC (Intelligent Data Acquisition Controller) interface board for the AT486 PC and other peripheral equipament were also manufactured by Syntech Laboratories.

\section{Experimental protocol}

Two sets of experiments were performed in order to elucidate the selectivity of the antennal receptors of $H$. 
grandella. In the first series of experiments, the general responsiveness of antennal receptors to individual oils (from T. ciliata and $C$. odorata) was measured by recording EAGs to volatile emanating from $10 \mu \mathrm{l}$ stimulus load of each volatile. Four replicates were obtained for each sex. In the second series of experiments, one of the two most effective oil (leaves of $T$. ciliata) were tested. The GC-EAD equipment was used in order to identify some individual compounds in the oil mixture capable to elicit an EAG response. Two replicates were obtained only for females.

\section{Statistical analyses}

EAGs were compared statistically using analysis of mean and standard deviation. The EAG software calculates the values automatically.

\section{Results and Discussion}

\section{Essential oils}

The composition of the essential oils is given in Table 1. Component concentrations were calculated from GC peak areas and they were arranged in order of GC (DB-5) elution. Inspection of Table 1 clearly shows that all the oils consist largely of sesquiterpenes. The oils from the leaves $(0.05 \%, \mathrm{~V} / \mathrm{W})$ and stems $(0.05 \%, \mathrm{~V} / \mathrm{W})$ of $T$. ciliata contained 36 and 31 components, of which $96 \%$ and $92 \%$ were identified, respectively. The major compounds in both samples were $\beta$-caryophyllene, germacrene-D and bicyclogermacrene. Globulol was present in both oil, but in substantial amounts $(12.50 \%)$ in the stems. Examination of the oils from the leaves $(0.23 \%, \mathrm{~V} / \mathrm{W})$ and stems $(0.03 \%$, $\mathrm{V} / \mathrm{W})$ of $C$. odorata indicated the presence of 32 and 47 components, of which $95 \%$ and $78 \%$ were identified, respectively. The main constituents in the latter were $\beta$ caryophyllene and caryophyllene oxide, while in the former were $\beta$-elemene and germacrene-A. The volatile oils from both species examined seem to be characterized by accumulation of large amounts of $\beta$-caryophyllene. However, leaf oil of $C$. odorata contained higher amount of $\beta$ elemene, but very low $\beta$-caryophyllene.

The chemical composition of volatile oils of juvenile and adult leaves of $C$. fissilis were poorly differentiated (Table 1). The only exception refers to the main constituents. The juvenile leaf oil has a higher percentage of $\mathrm{cis}$ 4(14),5-muuroladiene than the adult leaf oil. The latter produces bicyclogermacrene as the principal compound.

\section{Chemotaxonomic significance}

A summary of sesquiterpene types from $T$. ciliata, $C$. odorata and C. fissilis are presented in Tables 2-5. For all species the percentages of each structural types were added (e.g. bicyclogermacrane: T. ciliata: $27.92+38.46=66.38 \%$, Table 4). The skeletal types bicyclogermacrane, aromadendrane, aristolane, elemane, eudesmane, guaiane, germacrane and humulane can be assumed to derive from $2 E, 6-E$ farnesyl pyrophosphate (trans, Figures 1-2), while the types seychellane, boubonane, cadinane, copaane, cubebane, longifolane, himachalane, longipinane, caryophyllane, bisabolane, acorane, chamigrane and cedrane derive from 2Z,6E-farnesyl pyrophosphate (cis, Figures 3-5). Intermediate cationic species have been invoked to explain how the various structures arise ${ }^{14}$. Each cationic intermediate can of course undergo rearrangement, or suffer hydride shifts, and functional groups may be introduced or modified, as some reasonable pathways are shown in Figures 1-5.

Toona has in common so many sesquiterpenes with Cedrela (Table 4). All oils are characterized by higher percentage composition of trans- than the cis-farnesyl derivatives. Both derivatives belong to 6 different skeletal types represented by 9 compounds, though with total yield of trans- and cis-farnesyl derivatives of $108.64 \%$ and $42.94 \%$ in T. ciliata and $109.29 \%$ and $52.67 \%$ in $C$. odorata and $C$. fissilis altogether, respectively. There are, however according to Tables 3 and 5, also fairly consistent differences between the sesquiterpenes of Toona and Cedrela. $4 \alpha$-Methylaromadendranes T.1.1, T.1.2 and T.1.5 are known from the two latter, and T.1.3, T.1.4 and T.1.6 only from $T$. ciliata. The co-occurrence of bicyclogermacrane (T.1) and aromadendranes suggests that the biosynthesis of the latter compounds involves cyclization of a common bicyclogermacrane (T.1) precursor (Fig. 2). In this case, $T$. ciliata differs from $C$. odorata and $C$. fissilis by containing the enzyme systems necessary for both the cyclizations furnishing aromadendranes with a $4 \alpha-$ (T.1.1 and T.1.2) and $4 \beta$-methyl (T.1.3 and T.1.4) into five-membered ring.

In contrast, $4 \beta$-methyl-guaianes (T.2.3) occur in $C$. odorata and T. ciliata, whereas $4 \alpha$-methyl-guaianes (T.2.4, T.2.5 and T.3.3) are known only from $T$. ciliata (Fig. 1, Tables 3 and 4). All three species analysed develop cadinanes derived from the intermediates C.1.2 and C.1.1, the cubebanes from C.1.1 (C.1.1.6, Fig. 5) being restricted to Toona. Furthermore, $T$. ciliata contains representatives of aristolane (T.1.7), longifolane (C.1.3.1), bisabolane (C.2.1) and acorane (C.2.2), which do not seem to be common in C. odorata and C. fissilis. Copaane, longipinane, chamigrane, cedrane and eudesmane derivatives occur only in Cedrela (Table 5), but with highest concentrations in $C$. odorata, $C$. fissilis being limited to some cadinane (C.1.2.3.1 and C.1.1.1.2) and longipinane (C.1.3.3, Table 1). 


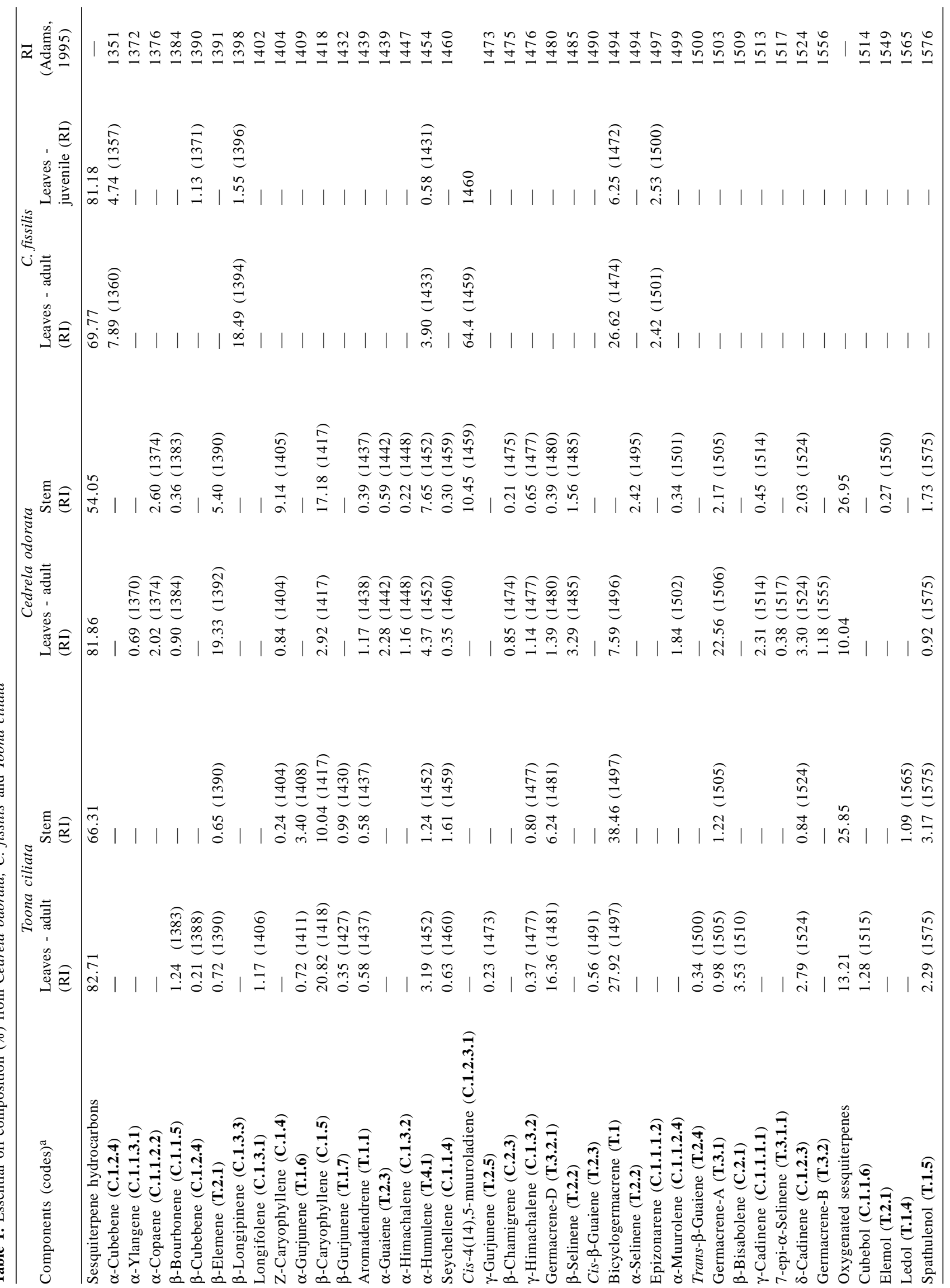


Table 2. A summary of sesquiterpene types ${ }^{\mathrm{a}}$ classified in the biogenetic maps

\begin{tabular}{|c|c|}
\hline Trans-farnesyl derivatives & Cis-farnesyl derivatives \\
\hline Bicyclogermacrane (T.1) & Seychellane (C.1.1.4) \\
\hline Aromadendrane $\left(\right.$ T.1.1 - T.1.6) ${ }^{\mathrm{b}}$ & Boubornane (C.1.1.5) \\
\hline Aristolane (T.1.7) & Cadinane (C.1.1.1.1 - C.1.1.1.2) \\
\hline Elemane (T.2.1) & Cadinane (C.1.1.2.1 - C.1.1.2.4) \\
\hline Eudesmane (T.2.2) & Copaane (C.1.1.2.2) \\
\hline Guaiane (T.2.3 - T.2.5) & Copaane (C.1.1.3.1) \\
\hline Guaiane (T.3.3) & Cubebane (C.1.1.6) \\
\hline Germacrane (T.3.1 - T.3.2.1) & Cubebane (C.1.2.4) \\
\hline Eudesmane (T.3.1.1) & Cadinane (C.1.2.1 - C.1.2.3.1) \\
\hline \multirow[t]{8}{*}{ Humulane (T.4.1 - T.4.1.1) } & Longifolane (C.1.3.1) \\
\hline & Himachalane (C.1.3.2) \\
\hline & Longipinane (C.1.3.3) \\
\hline & Caryophyllane (C.1.4 - C.1.5.1) \\
\hline & Bisabolane (C.2.1) \\
\hline & Acorane (C.2.2) \\
\hline & Chamigrane (C.2.3) \\
\hline & Cedrane (C.2.4) \\
\hline
\end{tabular}

$\overline{\text { aThe skeletal types are codified by letter and digits, which refer to }}$ the position of each skeletal type on the appropriate biogenetic map (Figures 1-5).

${ }^{b}$ The skeletal types (T.1.1 - T.1.6): from T.1.1 to T.1.6: T.1.1, T.1.2, T.1.3, T.1.4, T.1.5 and T.1.6.

Table 3. Sesquiterpene types identified only from Toona ciliata

\begin{tabular}{ll}
\hline $\begin{array}{l}\text { Trans-farnesyl } \\
\text { derivatives }(7 / 24.66 \%)^{\mathrm{a}}\end{array}$ & $\begin{array}{l}\text { Cis-farnesyl } \\
\text { derivatives }(6 / 11.84 \%)^{\mathrm{a}}\end{array}$ \\
\hline Aromadendrane $(3 / 21.87 \%)^{\mathrm{a}}$ & Cadinane $(2 / 3.49 \%)^{\mathrm{a}}$ \\
T.1.3 $(4.16+12.50)^{\mathrm{b}}$ & C.1.1.2.1 $(1.64+1.19)^{\mathrm{b}}$ \\
T.1.4 $(1.09)$ & C.1.2.2 $(0.66)$ \\
T.1.6 $(0.72+3.40)$ & Cubebane $(\mathbf{1} / \mathbf{1 . 2 8} \%)$ \\
Aristolane $(\mathbf{1} / \mathbf{1 . 3 4} \%)$ & C.1.1.6 $(1.28)$ \\
T.1.7 $(0.35+0.99)$ & Longifolane $(1 / 1.17 \%)$ \\
Guaiane $(\mathbf{3} / \mathbf{1 . 4 5} \%)$ & C.1.3.1 $(1.17)$ \\
T.2.4 $(0.34)$ & Bisabolane $(\mathbf{1} / \mathbf{3 . 5 3} \%)$ \\
T.2.5 $(0.23)$ & C.2.1 $(3.53)$ \\
T.3.3 $(0.88)$ & Acorane $(\mathbf{1} / \mathbf{2 . 3 7 \%})$ \\
& C.2.2 $(2.37)$
\end{tabular}

$\bar{a}$ Number of compound types and total percentage composition (21.87 $+1.34+1.45=24.66 \%$ )

bPercentage composition: see Table 1

The oils from $C$. odorata and $T$. ciliata were found to have markedly different chemical compositions to that identified by other workers. Representatives of cadinanes (cedrelanol; torreyol; $\alpha$-muurolene; $\gamma$-muurolene; calamenene), one copaane ( $\alpha$-copaene), one cubebane ( $\alpha$ cubebene), one guaiane (guaiazulene) and two elemanes ( $\beta$-elemene; $\delta$-elemene) have been reported from the former ${ }^{15-19}$. Of these sequiterpenes only $\alpha$-copaene and $\beta$-elemene were found in the present study. The second case is more interesting since the literature registers the occurrence of only $\alpha$-copaene in $T$. ciliata ${ }^{20}$. The oils of C. fissilis had not been analysed previously. 
Table 4. Sesquiterpene types identified from Toona ciliata, Cedrela odorata and C. fissilis ${ }^{\mathrm{a}}$

\begin{tabular}{|c|c|c|c|}
\hline \multicolumn{2}{|c|}{ Trans-farnesyl derivatives } & \multicolumn{2}{|c|}{ Cis-farnesyl derivatives } \\
\hline $\begin{array}{l}\text { Toona ciliata } \\
(9 / 108.64)^{\mathrm{b}}\end{array}$ & $\begin{array}{l}\text { Cedrela odorata }+C . \\
\text { fissilis }(9 / 109.29)^{\mathrm{b}}\end{array}$ & $\begin{array}{l}\text { Toona ciliata } \\
(9 / 42.94)^{b}\end{array}$ & $\begin{array}{l}\text { Cedrela odorata }+ \\
\text { C. fissilis }(9 / 52.67)^{\mathrm{b}}\end{array}$ \\
\hline Bicyclogermacrane $(1 / 66.38)^{\mathrm{b}}$ & $(1 / 34.21)^{\mathrm{b}}$ & Cadinane $(3 / 6.98)^{\mathrm{b}}$ & $(3 / 9.62)^{b}$ \\
\hline T.1 $(27.92+38.46)^{\mathrm{c}}$ & $(7.59+26.62)^{\mathrm{c}}$ & C.1.1.1.1 $(1.28+1.33)^{\mathrm{c}}$ & $(2.31+0.45)^{\mathrm{c}}$ \\
\hline Aromadendrane (3/11.1) & $(3 / 4.78)$ & C.1.2.1 (0.74) & $(0.84+0.69)$ \\
\hline T.1.1 $(0.58+0.58)$ & $(1.17+0.39)$ & C.1.2.3 (2.79 + 0.84) & $(3.30+2.03)$ \\
\hline T.1.2 $(1.16+3.32)$ & $(0.57)$ & Seychellane $(1 / 2.24)$ & $(1 / 0.65)$ \\
\hline T.1.5 $(2.29+3.17)$ & $(0.92+1.73)$ & C.1.1.4 $(0.63+1.61)$ & $(0.35+0.30)$ \\
\hline Elemane $(1 / 1.37)$ & $(1 / 25.00)$ & Bourbonane (1/1.24) & $(1 / 1.26)$ \\
\hline T.2.1 $(0.72+0.65)$ & $(19.33+5.40+0.27)$ & C.1.1.5 (1.24) & $(0.90+0.36)$ \\
\hline Guaiane $(1 / 0.56)$ & $(1 / 2.87)$ & Cubebane (1/0.21) & $(1 / 7.89)$ \\
\hline T.2.3 (0.56) & $(2.28+0.59)$ & C.1.2.4 (0.21) & $(7.89)$ \\
\hline Germacrane $(2 / 24.8)$ & $(2 / 26.51)$ & Himachalane (1/1.17) & $(1 / 3.17)$ \\
\hline T.3.1 $(0.98+1.22)$ & $(22.56+2.17)$ & C.1.3.2 $(0.37+0.80)$ & $(1.16+1.14+0.22+0.65)$ \\
\hline T.3.2.1 (16.36 + 6.24) & $(1.39+0.39)$ & Caryophyllane (2/31.1) & $(2 / 30.08)$ \\
\hline Humulane (1/4.43) & $(1 / 15.92)$ & C.1.4 (0.24) & $(0.84+9.14)$ \\
\hline T.4.1 $(3.19+1.24)$ & $(4.37+7.65+3.90)$ & C.1.5 (20.82 + 10.04) & $(2.92+17.18)$ \\
\hline
\end{tabular}

${ }^{\mathrm{a} C h e m o t a x o n o m i c ~ s t u d i e s ~ r e f e r ~ o n l y ~ t o ~ a d u l t ~ l e a v e s ~}$

bNumber of compound types and total percentage composition

${ }^{\mathrm{c} P e r c e n t a g e}$ composition: see Table 1

Table 5. Sesquiterpene types identified only from Cedrela odorata and C. fissilis ${ }^{\mathrm{a}}$

\begin{tabular}{|c|c|}
\hline Trans-farnesyl derivatives $(4 / 15.03)^{b}$ & Cis-farnesyl derivatives $(10 / 65.68)^{\mathbf{b}}$ \\
\hline Eudesmane $(2 / 11.09)^{\mathrm{b}}$ & Copaane $(2 / 5.31)^{\mathrm{b}}$ \\
\hline T.2.2 $(3.29+1.56+0.97+2.47+2.42)^{\mathrm{c}}$ & C.1.1.2.2 $(2.02+2.60)^{\mathrm{c}}$ \\
\hline T.3.1.1 (0.38) & C.1.1.3.1 (0.69) \\
\hline Germacrane $(1 / 1.18)$ & Cadinane $(4 / 16.23)$ \\
\hline T.3.2 (1.18) & C.1.1.2.3 (1.18) \\
\hline Humulane $(1 / 2.76)$ & C.1.1.2.4 $(1.84+0.34)$ \\
\hline \multirow[t]{10}{*}{ T.4.1.1 (2.76) } & C.1.2.3.1 (10.45) \\
\hline & C.1.1.1.2 (2.42) \\
\hline & Longipinane (1/18.49) \\
\hline & C.1.3.3 (18.49) \\
\hline & Caryophyllane (1/18.63) \\
\hline & C.1.5.1 $(0.78+17.85)$ \\
\hline & Chamigrane $(1 / 1.06)$ \\
\hline & C.2.3 $(0.85+0.21)$ \\
\hline & Cedrane $(1 / 5.96)$ \\
\hline & C.2.4 (5.96) \\
\hline
\end{tabular}

${ }^{\mathrm{a} C h e m o t a x o n o m i c ~ s t u d i e s ~ r e f e r ~ o n l y ~ t o ~ a d u l t ~ l e a v e s ~}$

${ }^{b}$ Number of compound types and total percentage composition

cPercentage composition: see Table 1

Based in the above evidences it is clear that Cedrela contains the main sesquiterpenes formed from the cis- and trans-farnesyl pyrophosphate [trans: $109.29 \%+15.03 \%$; cis: $52.67 \%+65.68 \%$ (Tables 4 and 5, respectively)]. In contrast, Toona tend to produce mainly sesquiterpenes formed from trans-precursor [trans: $108.64 \%+24.66 \%$; cis: $42.94 \%+11.84 \%$ (Tables 3 and 4, respectively)].
These interpretation of the sesquiterpene data and the fact that Toona differs from other genera of Swietenioideae ${ }^{7-9}$, notably by the absence of limonoids of the mexicanolide group, are consistent with Roemer's ${ }^{4}$ taxonomic conclusions, but suggested that the affiliation of Toona in the tribe Cedreleae together with Cedrela is still rather problematic. 

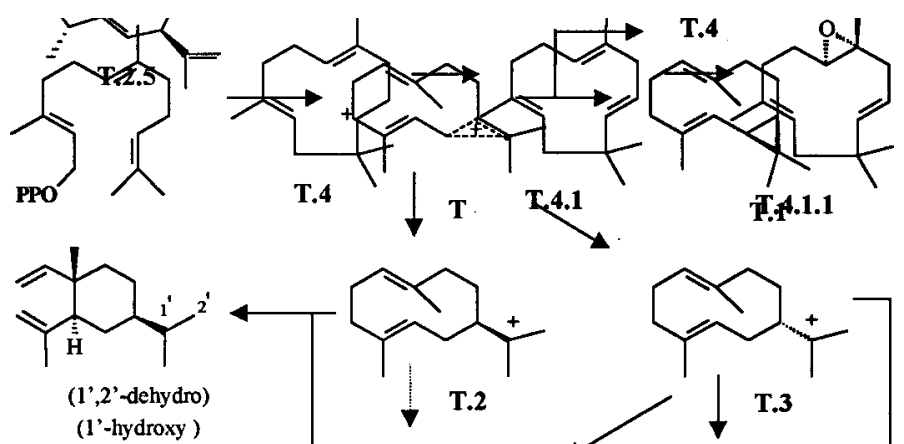<smiles>CC1=CCC=C2CCC([C+](C)C)CC12</smiles><smiles>CCCCCCCC</smiles>

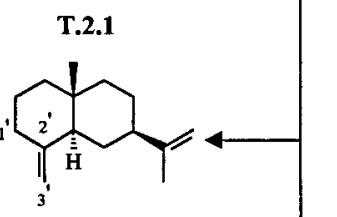

(1', 2'-dehydro, 2', 3'-dihydro) (2', 3'-dihydro, 2' $\beta$-hydroxy )

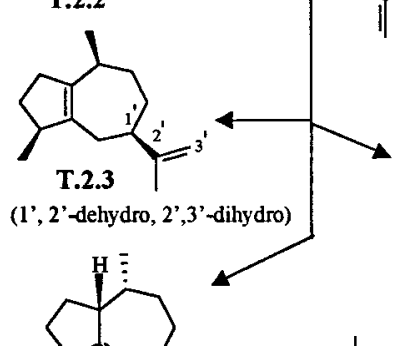<smiles>CC1=CCC=C2CCC(=C(C)C)CCC=C1C2</smiles><smiles>[132I-]</smiles>

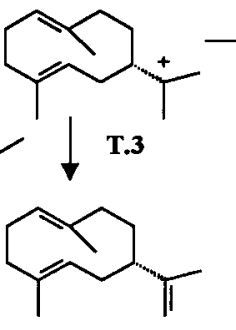<smiles>[AlH2]</smiles>

(1)<smiles>C=C1CCC2=CCC(C(C)C)CCC2C1</smiles><smiles>C=C(C)C1CC[C@]2(C)CCC=C(C)C2C1</smiles><smiles>CC(C)=C1CCC(C)C2=C1CCC2C</smiles><smiles>CCCCC(C)(C)O</smiles>

Figure 1. Part of a biogenetic map for sesquiterpenes featuring all structural types found in the oils from Toona ciliata, Cedrela odorata and C. fissilis (Tables 1-5). The codes (1, 2.1 etc.) refer to the position of the structural types on a map. The $\mathbf{T}$ letter indicates trans-farnesyl pyrophosphate as precursor.

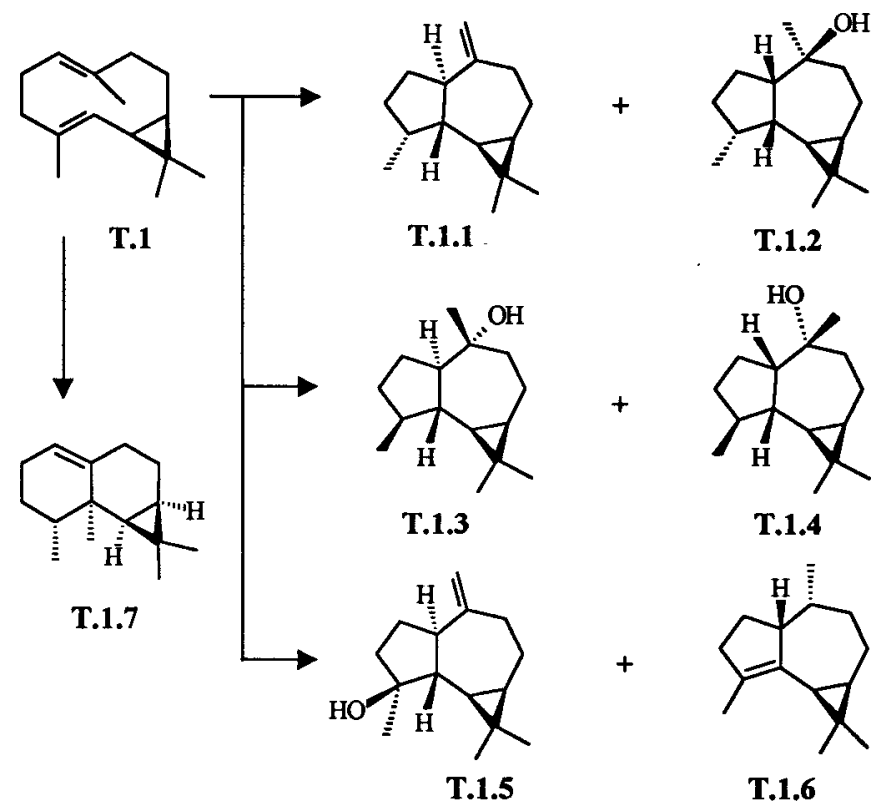

Figure 2. Part of a biogenetic map for sesquiterpenes featuring all structural types found in the oils from Toona ciliata, Cedrela odorata and $C$. fissilis (Tables 1-5). The codes $(\mathbf{1}, \mathbf{1 . 1}$ etc.) refer to the position of the structural types on a map. The $\mathbf{T}$ letter indicates trans-farnesyl pyrophosphate as precursor. 


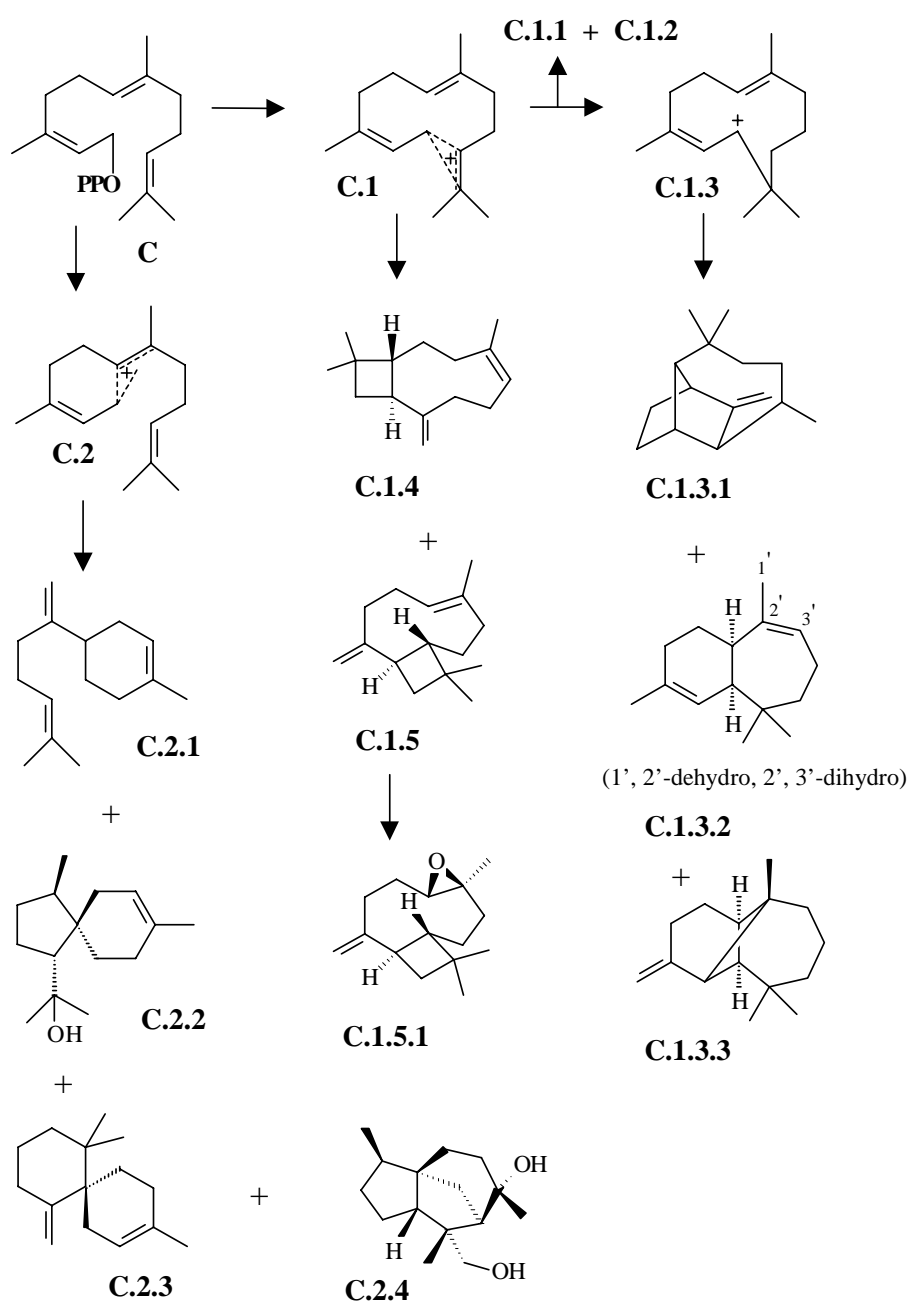

Figure 3. Part of a biogenetic map for sesquiterpenes featuring all structural types found in the oils from Toona ciliata, Cedrela odorata and $C$. fissilis (Tables 1-5). The codes $(\mathbf{1}, \mathbf{1 . 3}$ etc.) refer to the position of the structural types on a map. The $\mathbf{C}$ letter indicates cis-farnesyl pyrophosphate as precursor. C.1.1 and C.1.2: see Fig. 4.

\section{Ecological significance}

Mean electroantennogram responses (EAGs) to the essential oils from T.ciliata and C. odorata in H. grandella females, were significantly greater than those obtained for males (Figures 6 and 7). In addition, females were more selective to leaf oils than those from stems. The high selectivity of $H$. grandella female antenna to essential oils of $C$. odorata and T. ciliata, indicate its potential role as a chemical messengers for habitat location and oviposition (host-plant: genera of Swietenioideae ${ }^{9}$ ). Males, however, would not use similar information in its search behaviour, probably due to the fact that the relationship between males and the host-plant might not have the same importance. Furthermore, the results from EAGs to leaf oils from $T$. ciliata and $C$. odorata were not significantly different (e.g. Figure 6: -2.982 $\mathrm{mV}$ and $-3.073 \mathrm{mV}$, respectively), indicating that adult females would be unable to detect the differ- ent volatile compounds of both oils. The main constituents in the former were $\beta$-caryophyllene $(20.82 \%)$, germacrene-D (16.36\%) and bicyclogermacrene (27.92\%), while in the latter were $\beta$-elemene $(19.33 \%)$ and germacrene-A (22.56\%). They share only bicyclogermacrene as principal constituent (T.c. $=27.92 \%$, C.o. $=7.59 \%$ ). Attempts for locating potential components in leaf oils of T. ciliata by coupled GC-EAD failed (Figure 8). The absence of electrophysiological response might be related to an additive or synergistic effects of these compounds in the communication system of $H$. grandella female, which would not respond to an unique volatile, but to a mixture of two or more compounds. High EAG responses in previous expositions of the female antenna to the whole mixture confirm this theory (Figures 6-8). Field studies, optimal GC-EADs or/and EAG experiments with authentic samples are needed to clarify the role of essential oils in the $H$. grandella behaviour. 

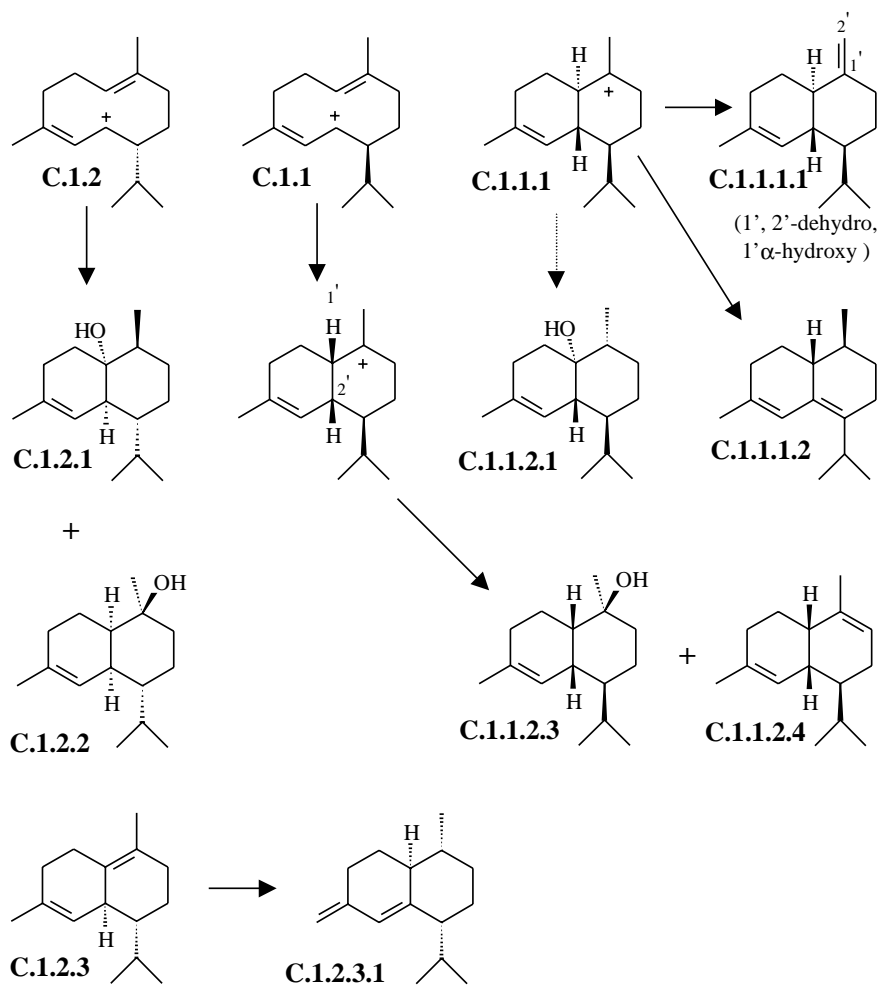

Figure 4. Part of a biogenetic map for sesquiterpenes featuring all structural types found in the oils from Toona ciliata, Cedrela odorata and C. fissilis (Tables 1-5). The codes (1.1, 1.1.1 etc.) refer to the position of the structural types on a map. The $\mathbf{C}$ letter indicates cis-farnesyl pyrophosphate as precursor.

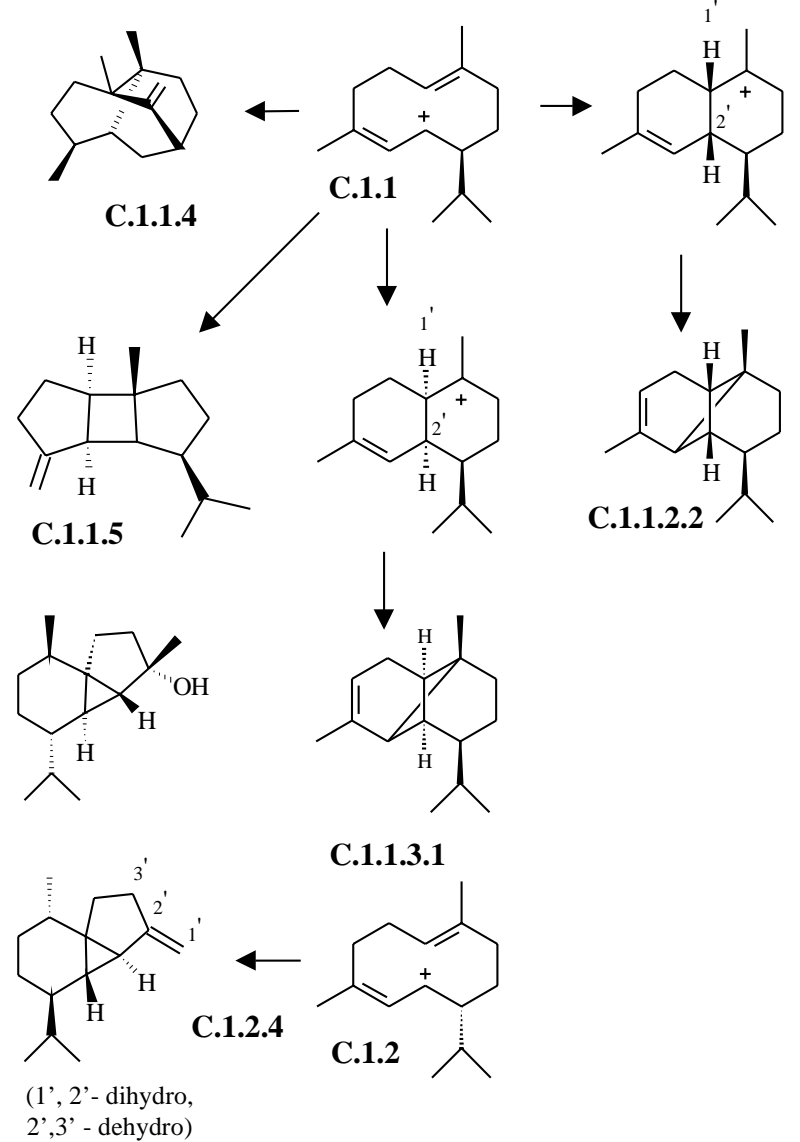

Figure 5. Part of a biogenetic map for sesquiterpenes featuring all structural types found in the oils from Toona ciliata, Cedrela odorata and C. fissilis (Tables 1-5). The codes $(\mathbf{1} .1, \mathbf{1} .1 .4$ etc.) refer to the position of the structural types on a map. The $\mathbf{C}$ letter indicates cis-farnesyl pyrophosphate as precursor. 


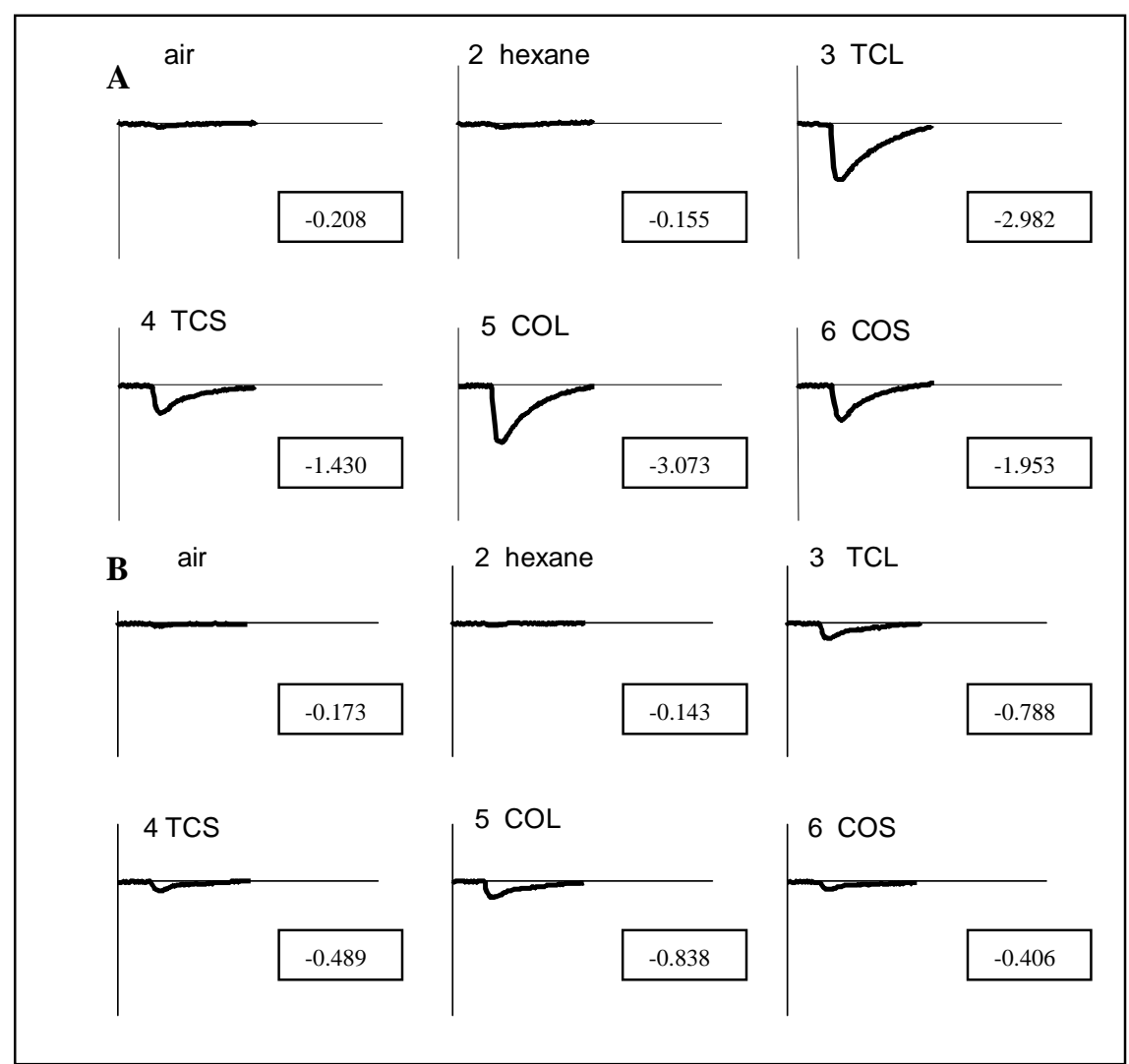

Figure 6. EAG responses of Hypsiphyla grandella females (A) and males (B) to essential oils from Toona ciliata (leaves: TCL, stems: TCS) and Cedrela odorata (leaves: COL, stems: COS) at $10 \mu 1$ stimulus load. Control: air and hexane. ${ }^{*}$ Responses in $\mathrm{mV}$.

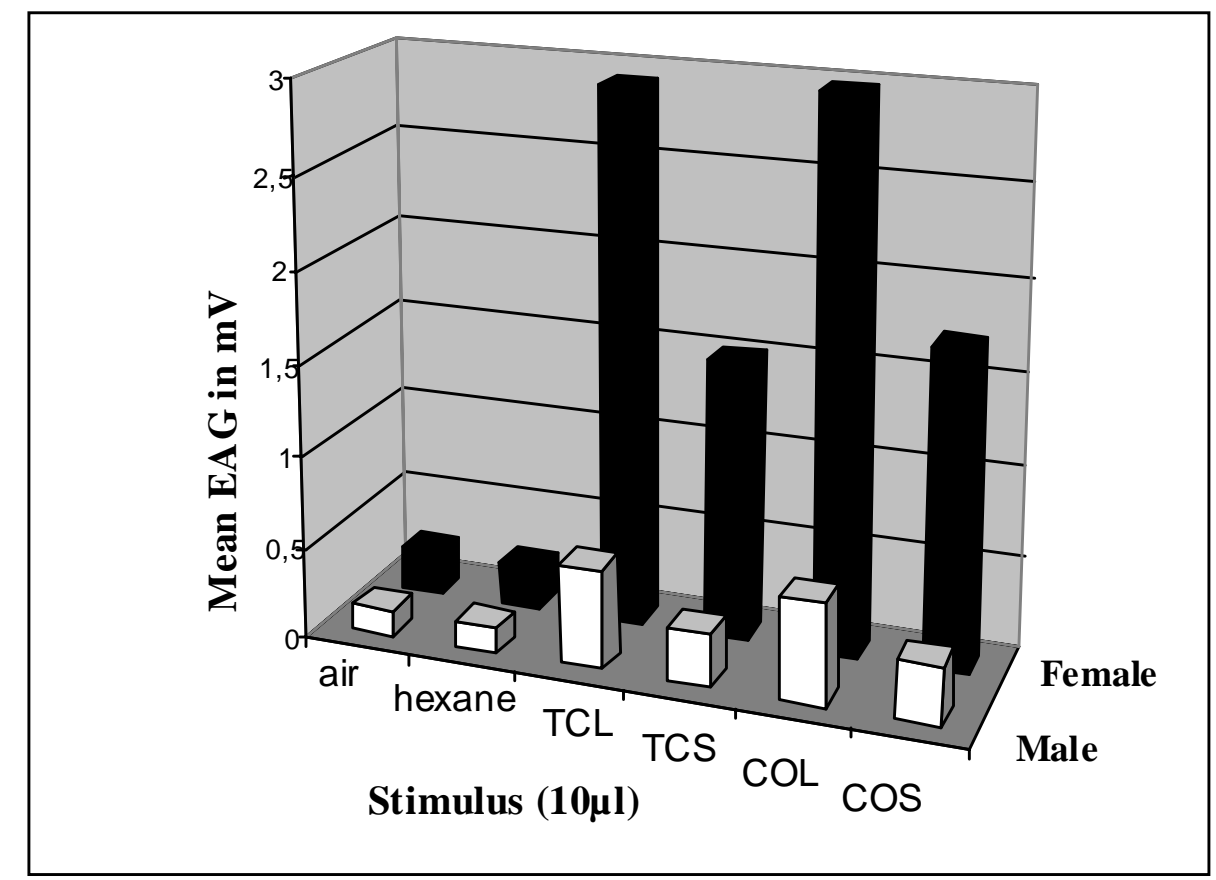

Figure 7. Mean EAG in millivolts elicited from Hypsipyla grandella males ( $\square$ ) and females ( $\mathbf{\square})$ antennae, in response to essential oils from Toona ciliata (leaves: TCL, stems: TCS) and Cedrela odorata (leaves: COL, stems: COS) at $10 \mu 1$ stimulus load. Control: air and hexane. 


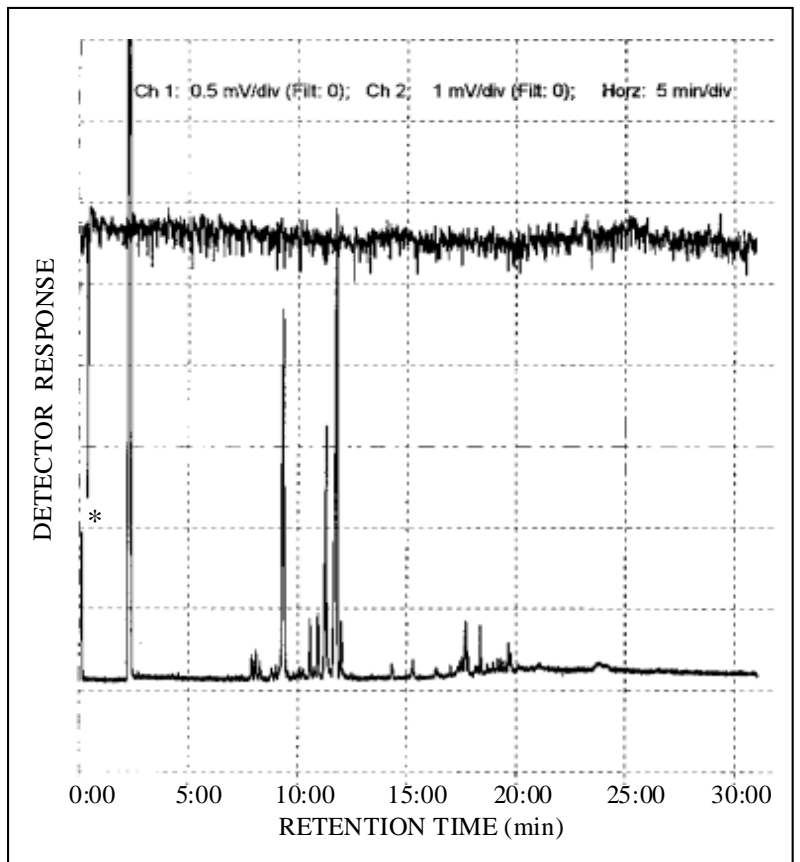

Figure 8. Simultaneously recorded EAD-FID chromatograms of Hypsipyla grandella female with FID responses to a essential oil (leaves) of Toona ciliata, injected under conditions described in the text. *Previous EAG response to the same oil tested prior to GC analysis.

\section{Acknowledgements}

The authors thank Conselho Nacional de Desenvolvimento Científico e Tecnológico (CNPq), Fundação de Amparo à Pesquisa do Estado de São Paulo (FAPESP) and Financiadora de Estudos e Projetos (FINEP) for the financial support. We also thank the Departamento de Biologia Animal, Universidade Federal de Viçosa, Viçosa, MG, Brazil, for laboratory facilities.

\section{References}

1. Grijipma, P. Turrialba 1970, 20, 85.

2. De Paula, J. R.; Vieira, I. J. C.; Silva, M. F. das G. F. da; Rodrigues-Fo, E.; Fernandes, J. B.; Vieira, P. C.; Pinheiro, A. L.; Vilela, E. F. Phytochemistry 1997, 44, 1449.

3. De Paula, J. R.; Castro-Gamboa, I.; Oiano-Neto, J.; Silva, M. F. das G. F. da; Rodrigues-Fo, E.; Fernandes,
J. B.; Vieira, P. C.; Pinheiro, A. L. An. Acad. Bras. Ci. 1998, 70, 737.

4. Roemer, M. J. Familiarum Naturalium Regni Vegetabilis Synopses Monographicae. I, Hesperides; 1846, p. 76.

5. Harms, H. In: Engler, A. and Prantl, K. (Eds.), Die Naturlichen Pflanzenfamilien; $2^{\text {nd }}$ edn, 1940, 19, bl, 1.

6. Pennington, T. D.; Styles, B. T. Blumea 1975, 22, 419.

7. Silva, M. F. das G. F. da; Gottlieb, O. R.; Dreyer, D. L. Biochem. Syst. Ecol. 1984, 12, 299.

8. Silva, M. F. das G. F. da; Gottlieb, O. R. Biochem. Syst. Ecol. 1987, 15, 85.

9. Agostinho, S. M. M.; Silva, M. F. das G. F. da; Fernandes, J. B.; Vieira, P.C.; Pinheiro, A. L.; Vilela, E. F. Biochem. Syst. Ecol. 1994, 22, 323.

10. Oiano-Neto, J.; Agostinho, S. M. M.; Silva, M. F. das G. F. da; Vieira, P. C.; Fernandes, J. B.; Pinheiro, A. L.; Vilela, E. F. Phytochemistry 1995, 38, 397.

11. Oiano-Neto, J.; Silva, M. F. das G. F. da; Rodrigues$\mathrm{F}^{\mathrm{O}}$, E.; Fernandes, J. B.; Vieira, P. C.; Pinheiro, A. L. Phytochemistry 1998, 49, 1369.

12. Dool; Van Den, H.; Kratz, P. Dec. J. Chromatog. 1963, $11,463$.

13. Adams, R. P. Identification of Essential Oil Components by Gas Chromatography Mass Spectroscopy; 1995. Allured Publishing Corporation, Illinois.

14. Mann, J. Secondary Metabolism; 1980. Oxford University Press, New York.

15. Campos, A. M.; Oliveira, F. S.; Machado, M. I. L.; Braz-Filho, R.; Matos, F. J. A. Phytochemistry 1991, 30, 1225.

16. Alderweireldt, F.; Chiurdoglu, G.; Smolders, R. R.; Soquet, A.; Verzele, M. Bull. Soc. Chim. Belg. 1961, 70, 470.

17. Smolders, R. R. Can. J. Chem. 1964, 42, 2836.

18. Smolders, R. R. Can. J. Chem. 1967, 45, 889.

19. Köng, W. A.; Rieck, A.; Hardt, I.; Gehrcke, B.; Kubeczka, K. H.; Muhle, H. J. High Resolut. Chromatogr. 1994, 17, 315.

20. Nagasampagi, B. A.; Yankov, L.; Dev, S. Tetrahedron Lett. 1968, 1913.

Received: July 24, 2000. 